\title{
Comparison of Effects of D-1 and D-2 Dopamine Receptor Agonists on Neurons in the Rat Caudate Putamen: An Electrophysiological Study
}

\author{
Xiu-Ti Hu and Rex Y. Wang \\ Department of Psychiatry and Behavioral Sciences, State University of New York at Stony Brook, Stony Brook, New York \\ 11794
}

Extracellular single-unit recording and microiontophoretic techniques were used to characterize the pharmacological properties of dopamine (DA) receptor subtypes within the rat caudate putamen $(\mathrm{CPu})$, a striatal structure that receives a dense innervation from DA neurons originating from the substantia nigra pars compacta (A9 DA neurons). Similar to the action of DA, the DA D-1 receptor agonist (+)SKF-38393 generally potentiated the activation produced by glutamate (GLU) at low ejection currents ( $\leq 5 \mathrm{nA})$; at higher ejection currents, it depressed $97 \%$ of the $\mathrm{CPu}$ neurons tested. By contrast, the D-2 receptor agonist LY-171555 (quinpirole) was much less effective in affecting the firing rate of $\mathrm{CPu}$ cells. The selective D-1 antagonist $\mathrm{SCH}-23390$, administered either intravenously or iontophoretically, completely blocked the (+)SKF-38393-induced effects on CPu cells but failed to change the depressant effects produced by either quinpirole or 5-HT. On the other hand, the selective D-2 antagonist -sulpiride, blocked the effects induced by quinpirole but not $(+)$ SKF-38393. These observations suggest that the $D-1$ and D-2 DA receptor agonists elicit their effects via distinct DA receptor subtypes. A comparison of these results with our previous results obtained from the nucleus accumbens (NAc) indicates that NAc cells are more responsive to DA D-2 agonist, whereas $C P u$ cells are more sensitive to $D-1$ agonist. Therefore, $\mathrm{D}-1$ receptors in the $\mathrm{CPu}$ may have a critical role in mediating the effect produced by DA.

Although intravenous injection of either quinpirole or (+)SKF-38393 induced little depression of CPu neuronal activity, administration of $(+)$ SKF-38393 following quinpirole induced a marked depressant effect on CPu neurons. However, concurrent iontophoresis of $(+)$ SKF-38393 and quinpirole onto $\mathrm{CPu}$ cells primarily produced an additive effect with little synergistic action. It is possible that the synergistic effect seen after intravenous DA D-1 and D-2 agonists is mediated primarily via DA receptor subtypes in different target areas.

\footnotetext{
Received Feb. 16, 1988; revised Apr. 20, 1988; accepted Apr. 21, 1988.

We thank Mrs. Jane Blanchard and Ms. Deyuan Jiang for expert technical assistance, Mrs. Judith Shivak for her assistance in manuscript preparation, and Dr. C. Ashby for reading the manuscript. We also thank Eli Lilly Co., Schering Corp., and Ravizza for their generous supplies of drugs. This work was supported by USPHS Grants MH-41440, MH-41696 and MH-00378 (RSDA) awarded to R.Y.W.

Correspondence should be addressed to Rex Y. Wang, Department of Psychiatry and Behavioral Sciences, State University of New York at Stony Brook, Putnam Hall, South Campus, Stony Brook, NY 11794.

Copyright (c) 1988 Society for Neuroscience $0270-6474 / 88 / 114340-09 \$ 02.00 / 0$
}

Dopamine (DA) receptors in the brain can be classified into at least 2 subtypes: the D-1 receptor, which is linked to a DAsensitive adenylate cyclase, and the D-2 receptor, which either has no effect or attenuates this enzyme's activity (Kebabian and Calne, 1979; Onali et al., 1981; Stoof and Kebabian, 1981; Meunier and Labrie, 1982; Creese et al., 1983). Previous studies have demonstrated that the D-2 receptor blockade is correlated with the therapeutic effect of antipsychotic drugs (see Seeman, 1987, for review); on the other hand, D-1 receptor stimulation is thought to be necessary for the expression of certain D-2 receptor-mediated effects (Gershanik et al., 1983; Morelli et al., 1986; Braun et al., 1987; Carlson et al., 1987; Starr et al., 1987; Walters et al., 1987; Weick and Walters, 1987b). The combination of selective D-1 and D-2 agonist revealed that the D-1 receptor agonist enables and potentiates the inhibitory action of D-2 receptor agonist (White and Wang, 1986; White, 1987).

Whether DA is an inhibitory or an excitatory neurotransmitter in the CNS is a source of controversy (for review, see Siggins, 1978; York, 1979; Wang et al., 1987). Most studies examining the effects of DA agonists and antagonists on the firing rate of caudate putamen $(\mathrm{CPu})$ cells find that DA usually produces a depressant effect, but some excitation occurs. DA has also been found to function as a neuromodulator in the CNS. For example, microiontophoretically applied DA at low current, which causes little or no inhibition of firing rate on $\mathrm{CPu}$ cells, has been found to enhance the glutamate (GLU)-evoked excitation and GABA-induced inhibition (Chiodo and Berger, 1986). DA also modulates the excitatory amino acid-gated conductances in cultured retinal horizontal cells (Knapp and Dowling, 1987) and attenuates the inhibitory effect of GABA on cells in the substantia nigra pars reticulata (Waszczak and Walters, 1982). A study by Johnson et al. (1983) suggested that neuromodulation may be a more important function of $\mathrm{DA}$ in the $\mathrm{CPu}$ than its effect on spontaneous firing rate.

It is unclear whether the DA-induced effects observed in the $\mathrm{CPu}$ were directly mediated via selective $\mathrm{D}-1$ and $\mathrm{D}-2$ receptor subtypes. For example, a recent study by Akaike et al. (1987) proposed that D-1 and D-2 receptors mediated inhibitory and excitatory response of $\mathrm{DA}$ in the $\mathrm{CPu}$, respectively. In contrast, Calabresi et al. (1987) reported that the selective D-1 agonist SKF-38393 (Setler et al., 1978; Sibley et al., 1982) mimicked the DA-induced inhibition, whereas selective D-2 agonist quinpirole, LY-171555 (Hahn et al., 1983; Fuller et al., 1985), had no effect on neostriatal cells.

In the present study, we have attempted to characterize the $\mathrm{DA}$ receptor subtypes within the rat $\mathrm{CPu}$ using the techniques 
of single-unit recording and microiontophoresis and to determine the functional role of D-1 and D-2 receptors in the regulation and/or modulation of $\mathrm{CPu}$ neuronal activity. We have previously compared the effects produced by D-1 and D-2 receptor agonists on cells in the nucleus accumbens (White and Wang, 1986). Since the target neurons of A10 and A9 DA systems have been implicated in mediating the therapeutic action and neurological side effects of antipsychotic drugs, respectively (Bunney and Grace, 1978; Chiodo and Bunney, 1983; White and Wang, 1983; Hand et al., 1987), the results may be offered as a first step in delineating the roles of DA receptor subtypes in the A9 and A10 DA systems underlying the mode of action of antipsychotic drugs (Hu and Wang, 1986; Hand et al., 1987).

\section{Materials and Methods}

Animals and surgery. Male Sprague-Dawley rats weighing 200-300 gm (Taconic, Germantown, NY) were used in the study. The rats were anesthetized with chloral hydrate $(400 \mathrm{mg} / \mathrm{kg}$, i.p.) and mounted in a stereotaxic apparatus. A lateral tail vein was cannulated for intravenous injection of additional anesthetic as necessary. A small burr hole was drilled over the $\mathrm{CPu}[10.3 \mathrm{~mm}$ anterior to the lambda, $2.5 \mathrm{~mm}$ lateral to the midline suture, according to the atlas of Paxinos and Watson (1982)]. All surgical procedures were performed in strict accordance with the Guiding Principles in the Care and Use of Animals of the Society for Neuroscience.

Single-cell recording and microiontophoresis. Standard extracellular single-cell recording and microiontophoretic techniques were employed as previously described (Wang et al., 1979; Wang, 1981). Five- or sixbarrel glass micropipettes, which had been pulled with a vertical electrode puller (Narishige PE2), were broken back under a microscope to a diameter of approximately $5-8 \mu \mathrm{m}$. The central barrel was filled with a $2 \mathrm{M} \mathrm{NaCl}$ solution saturated with $1 \%$ Fast green dye (Fisher). The in vitro impedance of the central (recording) barrel was 1-3 $\mathrm{M} \Omega$ measured at $135 \mathrm{~Hz}$ (Winston BL-1000B). One side barrel was filled with a $2 \mathrm{M}$ $\mathrm{NaCl}$ solution and was used for automatic current balancing. Another side barrel contained monosodium glutamate (GLU, $10 \mathrm{~mm}$ in $10 \mathrm{~mm}$ $\mathrm{NaCl}, \mathrm{pH} \mathrm{8;} \mathrm{Sigma).} \mathrm{The} \mathrm{rest} \mathrm{contained} 2$ or 3 of the following drugs: (+)SKF-38393(D-7,8-dihydroxy-1-phenyl-2,3,4,5-tetrahydro-1H-3benzazepine hydrochloride, $10 \mathrm{~mm}$, pH 4; Research Biochemicals Incorporated); quinpirole hydrochloride (LY-171555, $10 \mathrm{~mm}, \mathrm{pH} \mathrm{4}$; Eli Lilly); SCH-23390 [R-(+)-8-chloro-2,3,4,5-tetrahydro-3-methyl-5phenyl-1H-3-benzazepine-7 ol-hemimaleate, $10 \mathrm{mM}$, pH 4; Schering]; l-sulpiride (10 mM, pH 4; Ravizza); 5 -HT; creatinine sulfate monohydrate ( $10 \mathrm{~mm}, \mathrm{pH} 4$; Regis), and pindolol (10 mM, pH 4; Sandoz). For recording CPu cells, the micropipette was lowered to $3.5 \mathrm{~mm}$ below the cortical surface and via a hydraulic microdrive through the $\mathrm{CPu}$ to approximately $5.5 \mathrm{~mm}$ below the cortical surface. Electrical signals were passed through a high-impedance amplifier, displayed on an oscilloscope, monitored by an audioamplifier, and led into a window discriminator (Fintronics WDR 420) set such that the standard output was triggered by individual action potentials. Integrated rate histograms generated by the analog output of the window discriminator were plotted on a polygraph recorder (Gould 220). Retaining currents (positive for GLU and negative for the rest) of 8-10 nA were applied to drug barrels between ejection periods.

Intravenous drug administration. In some experiments, drugs were administered intravenously (i.v.) through the cannulated lateral tail vein. The specific DA D-1 and D-2 receptor agonists and antagonists were injected on a dose regimen in which each dose was twice that of the previously administered dose.

Histology. At the end of each experiment, the final recording site was marked by passing a $25 \mu \mathrm{A}$ cathodal current through the recording barrel for $15 \mathrm{~min}$. This resulted in the disposition of Fast green in a discrete spot. The rats were then perfused with a $0.9 \%$ saline followed by $10 \%$ buffered formalin. Serial coronal sections were cut at $50 \mu \mathrm{m}$ intervals, stained with cresyl violet, and counterstained with Neutral red. The dye spot was observed under a light microscope and served as a reference point for the location of each cell investigated.

Statistical procedures. The results from i.v. and iontophoretic experiments were compared using $\chi^{2}$ tests and 1-way analysis of variance (ANOVA), followed by Newman-Keuls tests for comparisons of specific means.
Table 1. Comparison of percentage of neurons in the caudateputamen (CPu) and nucleus accumbens inhibited by DA, D-1, and D-2 agonists

\begin{tabular}{|c|c|c|}
\hline \multirow[b]{2}{*}{ Compound } & \multicolumn{2}{|l|}{$\%$ of neurons } \\
\hline & NAc & $\mathrm{CPu}$ \\
\hline Iontophoresed DA & $95(20 / 21)$ & $94(30 / 32)$ \\
\hline Iontophoresed(+)SKF-38393 & $38(17 / 45)^{a, b}$ & $97(36 / 37)^{r, d}$ \\
\hline $\begin{array}{l}\text { Iontophoresed LY-141865 } \\
\text { or quinpirole }\end{array}$ & $75(30 / 40)^{a}$ & $43(13 / 30)^{e}$ \\
\hline $\begin{array}{l}\text { Intravenous LY-141865 } \\
\text { or quinpirole }\end{array}$ & $100(8 / 8)^{a}$ & $31(4 / 13)^{\gamma}$ \\
\hline
\end{tabular}

${ }^{a}$ Data from White and Wang (1986), in which LY-141865 was used.

"Significantly less than the percentage of NAc cells depressed by iontophoresed LY-141865 ( $\chi^{2}$ test, $\left.p<0.001\right)$.

c Significantly greater than the percentage of CPu cells depressed by iontophoresed quinpirole ( $\chi^{2}$ test, $\left.p<0.001\right)$.

${ }^{a}$ Significantly greater than the percentage of NAc cells depressed by iontophoresed $(+)$ SKF-38393 $\left(\chi^{2}\right.$ test, $\left.p<0.001\right)$.

- Significantly less than the percentage of NAc cells depressed by iontophoresed LY-141865 ( $\chi^{2}$ test, $\left.p<0.01\right)$.

$f$ Significantly less than the percentage of NAc cells depressed by i.v. LY-141865 (Fishers exact test of significance, $p=0.0024$ ).

\section{Results}

In the present experiments, we examined the effect produced by DA, selective D-1 and D-2 receptor agonists on both spontaneous and GLU-evoked activities of unidentified $\mathrm{CPu}$ neurons. A total of 111 histologically verified $\mathrm{CPu}$ neurons (54 spontaneously active and $57 \mathrm{GLU}$-evoked) were studied. Among these $111 \mathrm{CPu}$ cells, $100(90 \%)$ cells had the negative-positive waveform of type I cells, and the remaining 11 neurons (10\%) had the positive-negative waveform of type II cells (Skirboll and Bunney, 1979). Since the great majority of $\mathrm{CPu}$ cells exhibited the small, negative-positive waveform (amplitude was usually $200-500 \mu \mathrm{V}$ ), it is likely that type I cells correspond to the most frequently encountered "medium spiny neurons" reported in anatomical studies (see Chang et al., 1982, and references therein). However, results obtained from both type I and II cells were combined because they did not appear to exhibit different responsiveness to administered DA and DA agonists. Figure 1 is a photomicrograph of a coronal section of the rat brain illustrating a representative recording site (the Fast green spot) in the mid-CPu.

\section{Effects of $D A$ on $C P u$ cells}

As reported by Chiodo and Berger (1986), microiontophoretically applied DA at low currents (1-5 nA) facilitated GLUinduced activation ( 7 out of 9 cells tested; Fig. 2). However, at higher currents ( $\geq 10 \mathrm{nA}$ ), DA effectively suppressed the firing rate of both spontaneously active $(n=12)$ and GLU-evoked ( $n$ $=18) \mathrm{CPu}$ cells tested (30/32, or $94 \%$; Table 1$)$. Only 2 cells showed an increased firing rate in response to DA. The depressant action of DA was blocked by the typical antipsychotic drug haloperidol (HAL, $n=6$ ) but not by pindolol, which is an antagonist for serotonin (5-hydroxytryptamine or 5-HT) $5-\mathrm{HT}_{1 \mathrm{~b}}$ and $\beta$-adrenoceptor (Minneman et al., 1979; Titeler et al., 1987; Fig. 2).

\section{Effects of $D-1$ receptor agonist on $C P u$ cells}

Similar to the action of DA, when the D-1 specific agonist (+)SKF-38393 was iontophoresed at low currents (1-5 nA), it enhanced the activity evoked by GLU $(7 / 10$, or $70 \%$, of cells 
Figure 1. Representative photomicrograph illustrating that the Fast green spot (arrow), the placement of a 6-barrel micropipette, is within the mid-caudate putamen $(C P u)$. Broken lines demarcate the approximate boundary between the $\mathrm{CPu}$ and the nucleus accumbens $(N A C)$. Abbreviations: $L V$. lateral ventricle; $O T$, olfactory tubercle.

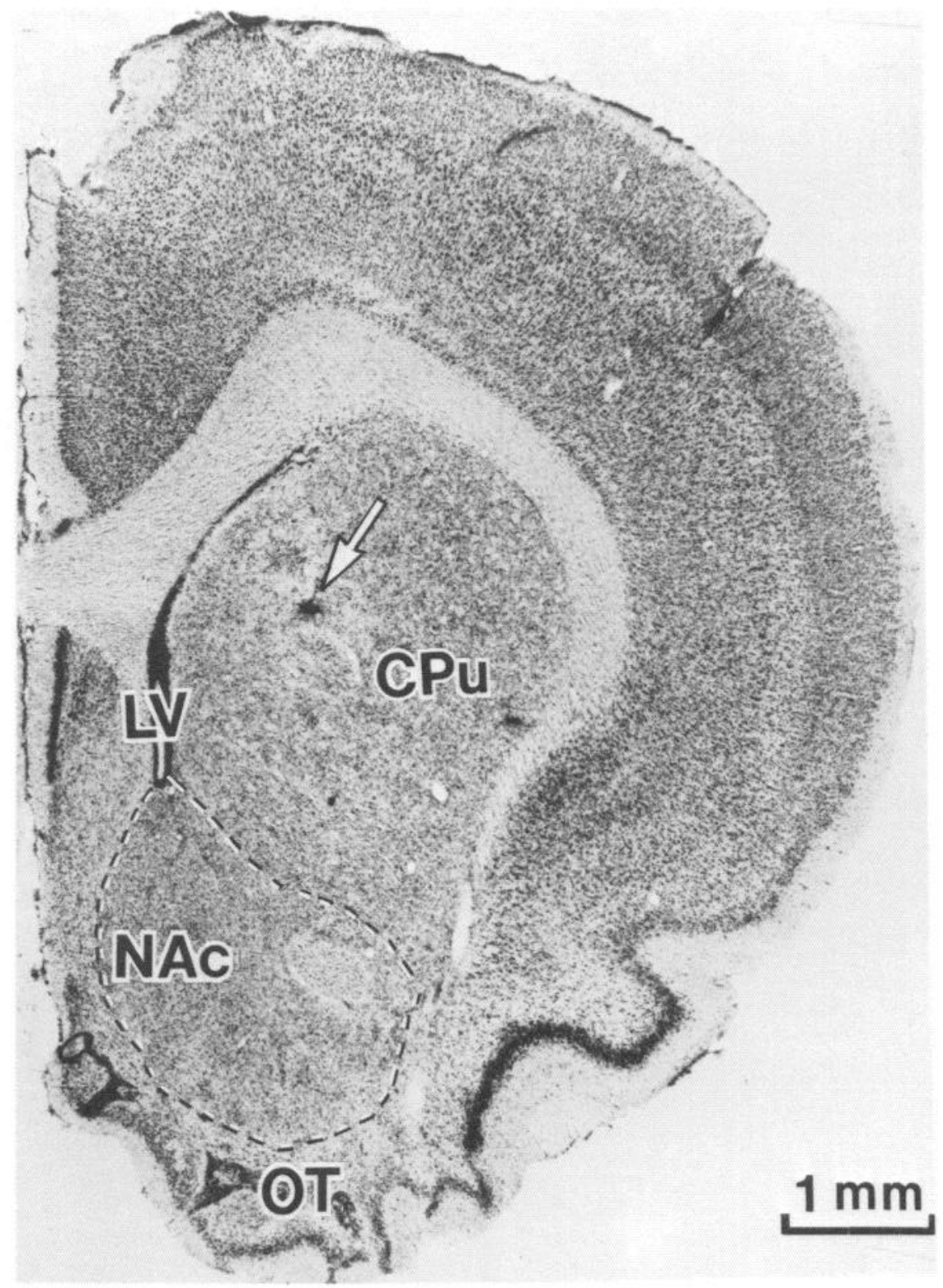

tested, Figs. 2 and 3$)$. The potentiation produced by low currents of $(+)$ SKF-38393 was blocked by SCH-23390 $(n=7)$, applied either iontophoretically or intravenously, but not by $l$-sulpiride (i.v., $1.5 \mathrm{mg} / \mathrm{kg}$, Fig. 3).

When (+)SKF-38393 was applied at the current of $10 \mathrm{nA}$ and higher (Fig. 4), it suppressed $\mathrm{CPu}$ neurons $(36 / 37$, or $97 \%$ ), whether the cell was spontaneously active or evoked by GLU. The extent of inhibition was dependent upon the amount of current delivered through the micropipette (see below). The (+)SKF-38393-induced depressant action was completely blocked by $\mathrm{SCH}-23390$, which was administered either directly by microiontophoresis ( $n=13$; Fig. $4, A$ and $B$ ) or indirectly by i.v. injection $\left(\mathrm{ED}_{100}\right.$ : $3.2 \pm 1.1 \mathrm{mg} / \mathrm{kg}, n=12$; Fig. $4 A$ ). The antagonistic action of $\mathrm{SCH}-23390$ was relatively selective in that it blocked the depressant effect produced by $(+)$ SKF-38393 but not that of 5 -HT $(n=6$; Fig. $4 A)$ or quinpirole $(n=4$; Fig. $5 C)$. Curiously, although HAL is primarily a DA D-2 antagonist (for review, see Tamminga and Gerlach, 1987), it also blocked the depressant effect of (+)SKF-38393 (Fig. 4C). In contrast to the antagonistic effect of SCH-23390 and HAL, $l$-sulpiride (the se- lective DA D-2 antagonist, $1-7 \mathrm{mg} / \mathrm{kg}$, i.v.) and pindolol (an antagonist for $5-\mathrm{HT}_{1 \mathrm{a}}, 5-\mathrm{HT}_{1 \mathrm{~b}}$ and $\beta$-adrenoceptor) failed to change the depressant effect induced by $(+)$ SKF-38393 $(n=5$; Fig. 4, $A$ and $D$ ).

\section{Effects of D-2 receptor agonist on CPu cells}

In contrast to the marked responses of $\mathrm{CPu}$ neurons to $\mathrm{D}-1$ agonist (+)SKF-38393, their responses to selective D-2 agonist quinpirole were weak and inconsistent. Low currents of quinpirole potentiated the GLU-evoked activity in only 2 out of 10 cells tested (Fig. 3). At higher currents, of the $30 \mathrm{CPu}$ neurons tested, iontophoresed quinpirole inhibited the firing activity of $13(43 \%$, including 10 GLU-activated and 3 spontaneously active $\mathrm{CPu}$ neurons; Fig. 5, $A$ and $B$ ), activated $3(10 \%)$, and produced no obvious effects on the remaining 14 cells (not shown). When quinpirole was effective in suppressing CPu cells, its action was consistently blocked by the D- 2 antagonist $l$-SUL, $(n=6$; Fig. $5, A$ and $B$ ) but not by the D-1 antagonist SCH$23390(n=4$; Fig. $5 C)$. 


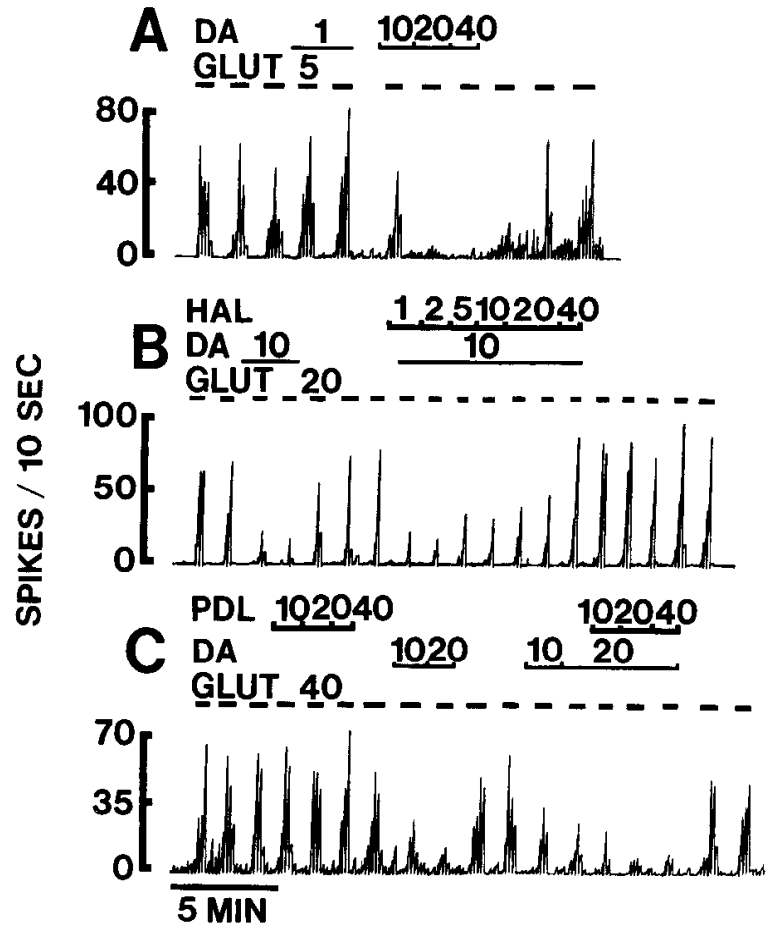

Figure 2. Cumulative rate histograms illustrating the effects produced by iontophoretic application of DA on CPu neurons. When DA was ejected at low currents ( $1 \mathrm{nA})$, it potentiated glutamate (GLUT)-induced activation $(A)$. In contrast, when it was ejected at higher currents $(\geq 10$ $\mathrm{nA}$ ), DA suppressed the firing rate of CPu cells $(A-C)$. The DA-induced effects were effectively blocked by the DA antagonist haloperidol $(H A L)$ but not by pindolol $(P D L)$, which is an antagonist for $5-\mathrm{HT}_{1 \mathrm{a}}, 5-\mathrm{HT}_{1 \mathrm{~b}}$ and $\beta$-adrenoceptor. Lines and numbers represent the duration of iontophoretic current and the amount of current (in $n A$ ), respectively.

\section{Comparison of effects of iontophoresed DA, D-I agonist, and D-2 agonist}

For a systematic comparison of the actions of DA, (+)SKF38393, and quinpirole on CPu neurons, current-response curves (using 10, 20,40, and $80 \mathrm{nA}$ ) for these compounds' inhibition of $\mathrm{CPu}$ cells were constructed. For each quiescent $\mathrm{CPu}$ neuron, an ejection current of GLU was chosen such that the firing rate induced by GLU was between $5-6 \mathrm{~Hz}$. Figure 6 shows that $\mathrm{CPu}$ neurons are significantly less sensitive to quinpirole $(n=30)$ than to DA $(n=32)$ and $(+) \operatorname{SKF}-38393(n=37)$. Note that the current-response curve for (+)SKF-38393 to suppress CPu cells is almost identical to that for DA.

To determine whether quiescent and spontaneously active cells differ in their sensitivity to D-1 and D-2 receptor agonists, the responses of both quiescent and spontaneously active $\mathrm{CPu}$ neurons to iontophoretically applied $(+)$ SKF-38393 and quinpirole were compared. At injection currents of 10, 20, and 40 $\mathrm{nA}, \mathrm{GLU}$-evoked quiescent neurons $(n=25)$ were significantly more sensitive to $(+)$ SKF-38393 than spontaneously active neurons ( $n=14$; Newman-Keuls tests, $p<0.05$ ), whereas at higher currents ( 80 and $120 \mathrm{nA}$ ), no significant difference was observed between the 2 groups (Fig. $7 A$ ). In contrast, for quinpiroleinduced depression, there was no significant difference betwecn the quiescent $(n=17)$ and spontaneously active $(n=14)$ cell groups (Fig. 7B).

\section{Effects of i.v. quinpirole and $(+) S K F-38393$ on CPu neurons}

Intravenous administration of quinpirole at low doses $(1-15 \mu \mathrm{g} /$ $\mathrm{kg}$ ) caused an initial rate increase (20-30\%) in 8 of 12 spontaneously active $\mathrm{CPu}$ neurons tested (Fig. $8 \mathrm{C}$ ) but did not change the discharge rate in the remaining 4 cells (Fig. $8 A$ ). At higher doses (up to $1.023 \mathrm{mg} / \mathrm{kg}$ ), of the 8 cells showing the initial rate increase, one cell remained activated, 3 cells returned to basal firing level, and 4 cells further decreased their firing activity; of the 4 cells that did not respond to low doses of quinpirole, higher doses of quinpirole increased the firing activity on 3 cells and produced no effect on one.

Intravenous administration of (+)SKF-38393 at low doses (1-15 $\mu \mathrm{g} / \mathrm{kg}$ ) produced little or no effect on the discharge rate of 12 spontaneously active $\mathrm{CPu}$ cells tested. At higher doses, $(+)$ SKF-38393 increased the firing rate of one cell, decreased the firing activity of 6 cells, and produced no obvious effect on the remaining 5 cells $(1-10 \mathrm{mg} / \mathrm{kg}$; Fig. $8, B$ and $D)$. Interestingly, when $(+)$ SKF-38393 was injected after quinpirole $(1.023 \mathrm{mg} /$ $\mathrm{kg}$, i.v.), the ability of $(+) \mathrm{SKF}-38393$ to depress the neuronal activity of $\mathrm{CPu}$ cclls was markedly enhanced ( $n=9$; Fig. 8$)$; the $\mathrm{ID}_{50}$ value was $0.19 \pm 0.06 \mathrm{mg} / \mathrm{kg}$.

Effects of concurrent iontophoretic application of $(+) S K F-$ 38393 and quinpirole on CPu neurons

To determine whether there was a direct synergistic interaction between D-1 and D-2 receptor agonists on CPu cells, $(+) \mathrm{SKF}$ 38393 and quinpirole were iontophoresed concurrently onto 9 $\mathrm{CPu}$ neurons. Only 2 cells (22\%) showed an enhanced depressant

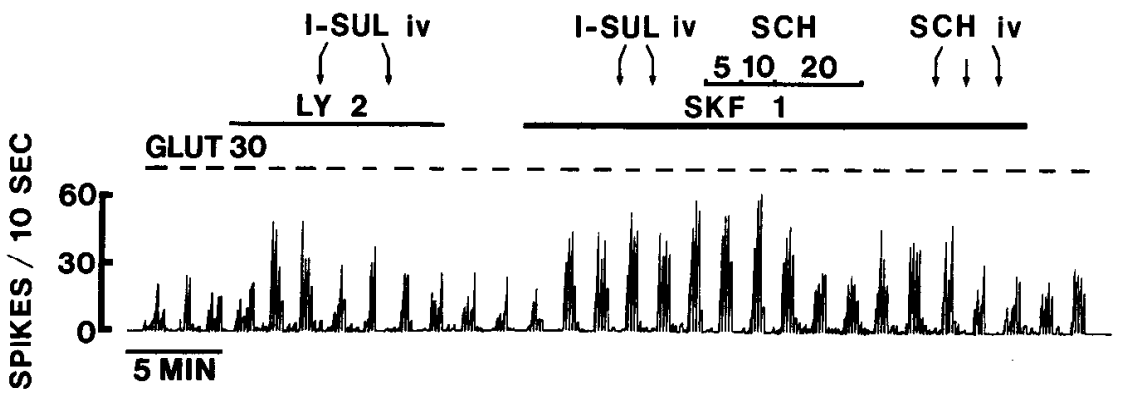

Figure 3. Representative cumulative rate histograms showing that iontophoretic application of either quinpirole or $(+)$ SKF-38393 facilitates glutamate $(G L U T)$-induced excitatory effect on a CPu cell. When they were applied at low currents, both quinpirole $(\mathrm{LY}-171555,2 \mathrm{nA})$ and $(+)$ SKF$38393(1 \mathrm{nA})$ facilitated glutamate-induced activation. Intravenous administration of the D-2 receptor antagonist $l$-sulpiride $(l-S U L, 1.5 \mathrm{mg} / \mathrm{kg})$ effectively blocked the facilitating action of quinpirole but not that of (+)SKF-38393 (even with a total of $3 \mathrm{mg} / \mathrm{kg} l-\mathrm{SUL}$ ). In contrast, the D-1 receptor antagonist SCH-23390 applied either iontophoretically $(20 \mathrm{nA})$ or i.v. (arrows indicate the injection of 1,2 , and $4 \mathrm{mg} / \mathrm{kg}$, respectively) reversed the facilitating action of $(+)$ SKF-38393. 
Figure 4. Cumulative rate histograms illustrating that the action of $(+)$ SKF38393 on CPu cells is mediated by DA D-1 receptor subtype. Iontophoresis of the D-1 specific agonist (+)SKF-38393 depressed both glutamate ( $G L U T)$ evoked $(A, C$, and $D)$ and spontaneous activity $(B)$ of CPu cells. The depressant effect produced by $(+)$ SKF-38393 was blocked by either the D-1 antagonist SCH-23390 $(A$ and $B)$ or DA antagonist haloperidol $(I I A L ; C)$. In contrast, ncither $l$-sulpiride (the DA D-2 antagonist) $(A)$ nor pindolol (a 5-HT $1 \mathrm{a}, 5-\mathrm{HT}_{1 \mathrm{~b}}$ and $\beta$-adrenoceptor antagonist) $(D)$ was effective in antagonizing the depression produced by $(+)$ SKF-38393. The antagonizing effect of SCH-23390 was selective in that it blocked the depressant action of $(+)$ SKF-38393 but not that of 5 -HT $(A)$. Intravenous administration of SCH-23390 (total dose, $7 \mathrm{mg} / \mathrm{kg}$ ), but not 1 -sulpiride (total dose, $7 \mathrm{mg} / \mathrm{kg}$ ), also blocked the depressant effect produced by action of $(+)$ SKF-38393.

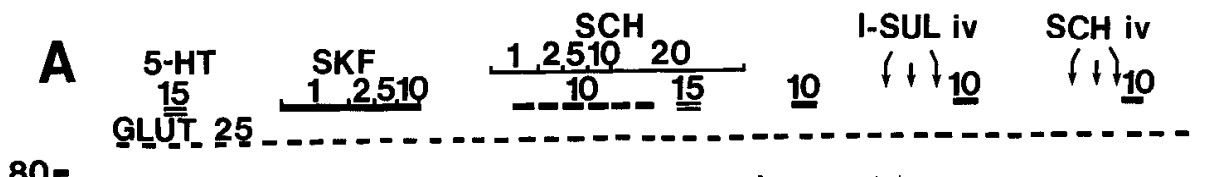

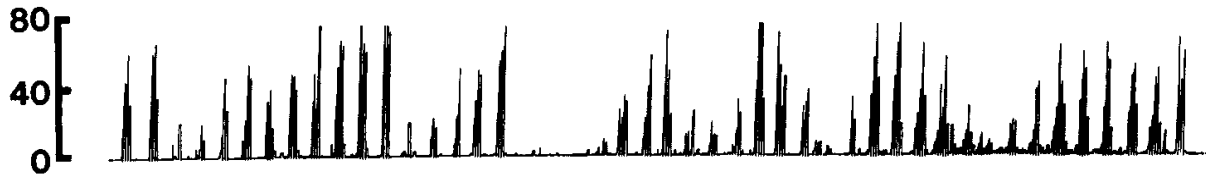
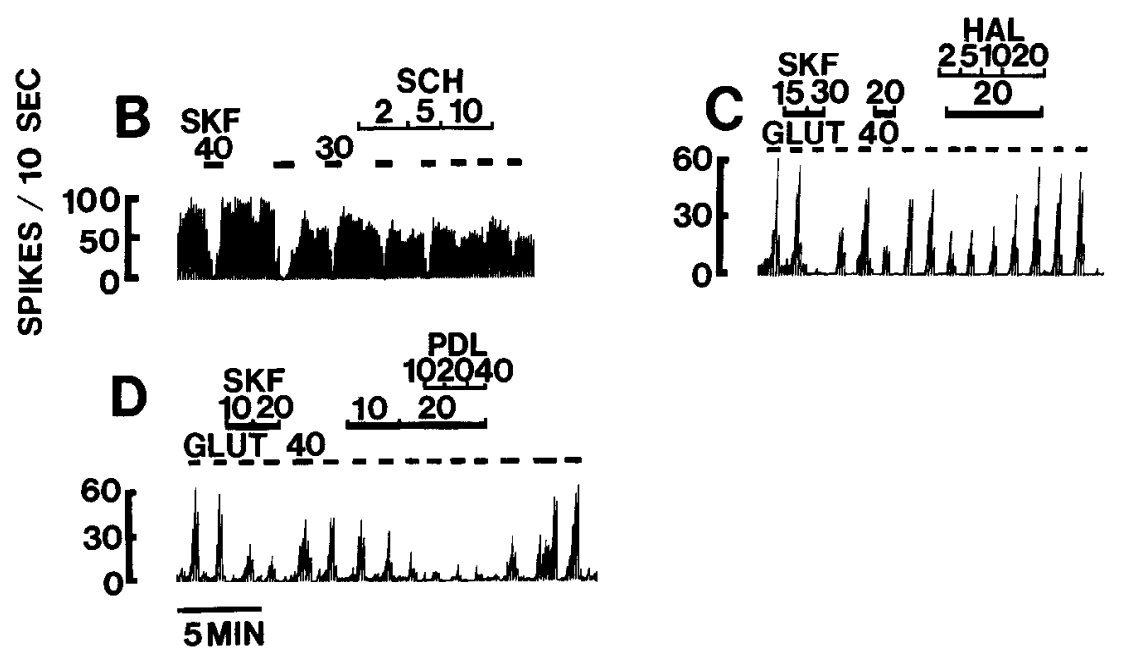

response to combined (+)SKF-38393 and quinpirole. In the remaining 7 cells, $(+)$ SKF-38393 and quinpirole produced a simple additive effect.

Comparison of inhibitory effects of $D A,(+) S K F-38393$, and quinpirole in the CPu versus nucleus accumbens (NAc)

To compare the effect induced by DA and DA agonists on $\mathrm{CPu}$ and NAc cells, the response of the latter to iontophoresed DA was studied. Similar to the effect seen in the $\mathrm{CPu}, \mathrm{DA}$ at low current enhanced GLU-induced activation and at high current ( $\geq 10 \mathrm{nA}$ ) markedly suppressed the neuronal activity on almost all NAc cells tested $(20 / 21$ or $97 \%$; Table 1$)$. Table 1 lists the percentage of CPu and NAc cells depressed by DA and D-1 and D-2 agonists. Some results obtained from the NAc cells were taken from a previous study in this laboratory (White and Wang, $1986)$ in which the same concentrations (10 mM) of (+)SKF38393 and LY-141865 (a racemate of quinpirole) were administered iontophoretically and similar ejection currents were applied. In the earlier study we demonstrated that more NAc cells were inhibited by LY-141865 than (+)SKF-38393. In contrast, although quinpirole (LY-171555, an active enantiomer of LY141865 ) is a more potent D-2 agonist than LY-141865 (Martin et al., 1986), it was still significantly less effective than (+)SKF38393 in depressing the firing activity of CPu cells (Table 1). These combined results indicate that, whereas the D-2 agonist is significantly morc efficacious in depressing the activity of NAc than $\mathrm{CPu}$ cells, the reverse is true for the $\mathrm{D}-1$ agonist.

\section{Discussion}

In the present study, we confirmed that iontophoresis of DA (ionto-DA) at low currents does not affect the firing rate of $\mathrm{CPu}$ cells but facilitates GLU-induced activation (Chiodo and Berger, 1986) and at high currents DA suppresses the activity of $\mathrm{CPu}$ cells (Siggins, 1978). The action of DA was mimicked by
DA agonists (see below) and was blocked by the DA antagonist HAL but not by the 5-HT ${ }_{1 \mathrm{a}}, 5-\mathrm{HT}_{1 \mathrm{~b}}$ and $\beta$-adrenoceptor antagonist pindolol (Minneman et al., 1979; Titeler et al., 1987), suggesting that these actions were mediated by DA receptors. The results support the concept that, besides acting as a neurotransmitter, DA also has a role as a neuromodulator in the CNS (Waszczak and Walters, 1982; Johnson et al., 1983; Chiodo and Berger, 1986; Knapp and Dowling, 1987).

Similar to the action of DA, the selective D- 1 receptor agonist $(+)$ SKF-38393 at low currents did not change the firing rate of $\mathrm{CPu}$ cells but markedly potentiated the responses of $\mathrm{CPu}$ neurons to GLU. At higher currents, however, (+)SKF-38393 effectively depressed the spontaneous and GLU-evoked activity on almost all $\mathrm{CPu}$ neurons tested. The current-response curves for DA and $(+)$ SKF-38393 are almost identical. Both the "modulatory" and "inhibitory" effects produced by (+)SKF-38393 on $\mathrm{CPu}$ cells was cffcctivcly blocked by the selective D-1 receptor antagonist SCH-23390 but not by $l$-sulpiride (the DA $\mathrm{D}-2$ receptor antagonist) or pindolol (a $5-\mathrm{HT}_{1 \mathrm{a}}, 5-\mathrm{HT}_{1 \mathrm{~b}}$ and $\beta$-adrenoceptor antagonist). The antagonistic action of $\mathrm{SCH}$ 23390 is relatively specific in that it blocks the depressant action of $(+)$ SKF-38393 but not that of 5-HT or quinpirole. In contrast to the results obtained with $(+)$ SKF-38393 and DA, microiontophoretically applied D-2 agonist quinpirole was comparatively ineffective in altering the firing activity of $\mathrm{CPu}$ cells. In the few cases where quinpirole did depress $\mathrm{CPu}$ cells, the effect was antagonized by $l$-sulpiride but not by $\mathrm{SCH}-23390$. Although the precise amount of D-1 and D-2 receptor agonists ejected by iontophoretic currents is unknown, it seems unlikely that the possible difference in the transport number for $(+)$ SKF-38393 and quinpirole can account for the preferential reaction of $\mathrm{CPu}$ cells to (+)SKF-38393: As shown in a previous study (White and Wang, 1986), we have used similar micropipettes containing the same concentration of the $(+)$ SKF-38393 and LY-141865 


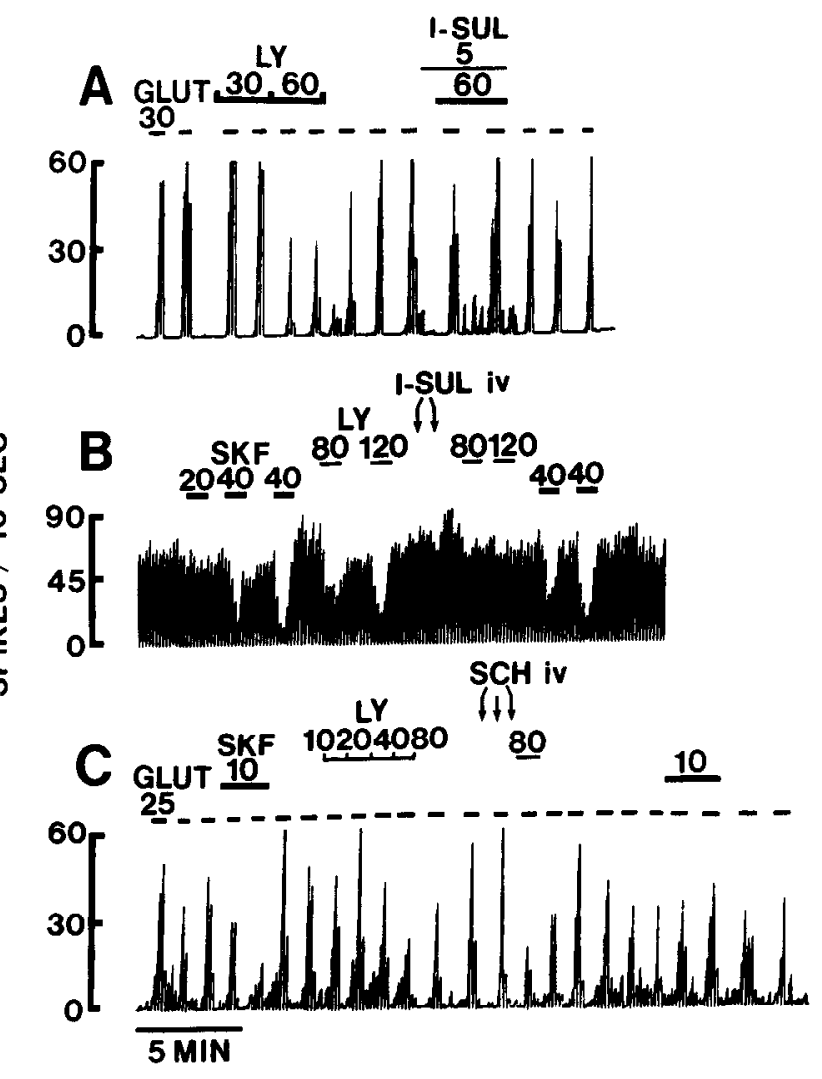

Figure 5. Cumulative rate histograms illustrating that, compared with D-1 specific agonist $(+)$ SKF-38393, D-2 specific agonist quinpirole ( $L Y$ 171555 ) is less effective in depressing the firing activity of CPu cells. In $A$, iontophoresis of quinpirole at high currents suppressed glutamate (GLUT)-evoked activity on a $\mathrm{CPu}$ cell; the quinpirole-induced effect was blocked by iontophoretically applied $l$-sulpiride. Both spontaneously active $(B)$ and quiescent $(C) \mathrm{CPu}$ neurons were more responsive to D-1 agonist $(+)$ SKF-38393 than to D-2 agonist quinpirole. The depressant effects produced by $(+)$ SKF-38393 and quinpirole were blocked by i.v. administrations of SCH-23390 and $l$-sulpiride, respectively. The total dose for $l$-sulpiride and SCH-23390 was 3 and $7 \mathrm{mg} / \mathrm{kg}$, respectively.

and found that NAc neurons were more responsive to the D-2 than $D-1$ receptor agonist. Taken together, these results suggest that (1) D-1 and D-2 DA agonists exerted their action via distinct $\mathrm{DA}$ receptor subtypes in the $\mathrm{CPu}$, and (2) the effect of DA in the $\mathrm{CPu}$ is primarily mediated by $\mathrm{D}-1$ receptors. The latter view is supported by a series of receptor binding studies (George et al., 1985; Grigoriadis and Seeman, 1985; Seeman et al., 1986), showing that DA has a 10 -fold higher affinity for postsynaptic $D-1$ receptors than for D-2 receptors in the calf caudate nucleus and the rat striatum (DA has dissociation constants of about 0.1 and $1 \mathrm{nM}$ for the high-affinity state of D-1 and D-2 receptors, respectively). The greater sensitivity of $\mathrm{CPu}$ cells to $\mathrm{D}-\mathrm{l}$ agonist is also in agreement with biochemical studies showing the high density of DA-sensitive adenylate cyclase in the rat neostriatum and with electrophysiological studies showing that iontophoresis of cyclic AMP inhibits the majority of CPu neurons (Siggins et al., 1974).

Following i.v. administration, quinpirole in most cases caused only an initial increase in cell activity and at higher doses it failed to inhibit $\mathrm{CPu}$ neuronal activity. The result contrasts with the biphasic increase/decrease effect on the firing rate of NAc cells produced by the selective D-2 receptor agonist LY-141865

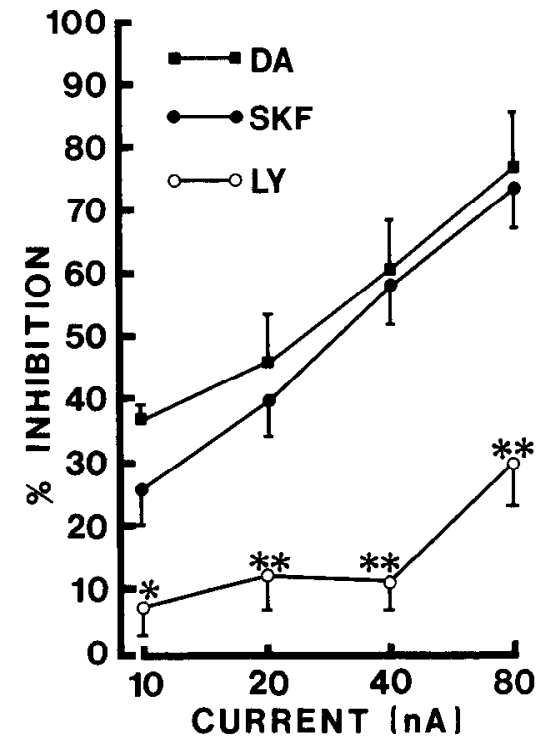

Figure 6. Comparison of the current-response curves for DA, $(+) \mathrm{SKF}-$ 38393, and quinpirole (LY-171555) to depress the activity of CPu neurons. $\mathrm{CPu}$ neurons were significantly less sensitive to iontophoretically administered quinpirole $(n=30)$ than to DA $(n=30)$ and $(+)$ SKF38393 ( $n=37)$. Each dala point represents the mean percentage inhibition \pm SEM. Asterisks represent points that significantly differ from the corresponding DA points $\left(^{*} p<0.05,{ }^{* *} p<0.01\right.$; ANOVA with Newman-Keuls tests)

(White and Wang, 1986; Hu and Wang, 1988). There is evidence suggesting that the initial increase produced by the D-2 agonists on NAc and CPu cells is the result of disinhibition, and the rate suppression is the direct action of D-2 agonist on NAc cells (White and Wang, 1986; Hu and Wang, 1988). Therefore, the failure of high doses of quinpirole to inhibit CPu cells is consistent with the iontophoretic result that quinpirole is not very active on CPu cells. This view is further reinforced by an intracellular single-unit study (Calabresi et al., 1987) in which SKF-38393 mimicked the DA-induced depressant effect on neostriatal cells, but quinpirole had little effect. At variance with our results are studies showing that the excitatory response of $\mathrm{CPu}$ cells to DA might be mediated by D-2 receptors (Ohno et al., 1986; Akaike et al., 1987). We and other investigators (Bernardi et al., 1978; Herrling and Hull, 1980; Calabresi et al., 1987) have not consistently observed the excitatory action of quinpirole or DA. If activation of DA D-2 receptors in the $\mathrm{CPu}$ produced the excitatory response, these receptors should be different from DA D-2 autoreceptors because activation of the DA autoreceptor produces an inhibitory action (hyperpolarization and an increase of potassium conductance) on both A9 (Pinnock, 1984; Silva and Bunney, 1986; Lacey et al., 1987) and A10 DA neurons (White and Wang, 1986; White, 1987). So far, there is no compelling evidence suggesting that postsynaptic $D-2$ receptors and D-2 autoreceptors are of different subtypes, although this possibility cannot be ruled out.

We showed that iontophoresis of DA and selective D-1 receptor agonist $(+)$ SKF-38393 at high currents produced predominantly, if not exclusively, a depressant action on $\mathrm{CPu}$ cells. Our results are consistent with those from previous electrophysiological studies (Siggins et al., 1974; Akaike et al., 1987). They are also in line with the results from recent ultrastructural studies which demonstrated that tyrosine hydroxylase (TH)containing terminals in the $\mathrm{CPu}$ form primarily symmetrical 
Figure 7. Comparison of the currentresponse curves for $(+)$ SKF-38393 and quinpirole to inhibit spontaneously active and glutamate-evoked quiescent $\mathrm{CPu}$ neurons. Compared with spontaneously active cells $(n=30)$, quiescent neurons were significantly more sensitive to iontophoretically administered $(+)$ SKF-38393 $(n=37)$ at currents of 10,20 , and $40 \mathrm{nA}$, although not at 80 or $120 \mathrm{nA}\left(A *^{*} p<0.05\right.$, ANOVA with Newman-Keuls tests). There was no significant difference in the responsiveness of the 2 cell groups to quinpirole (B).

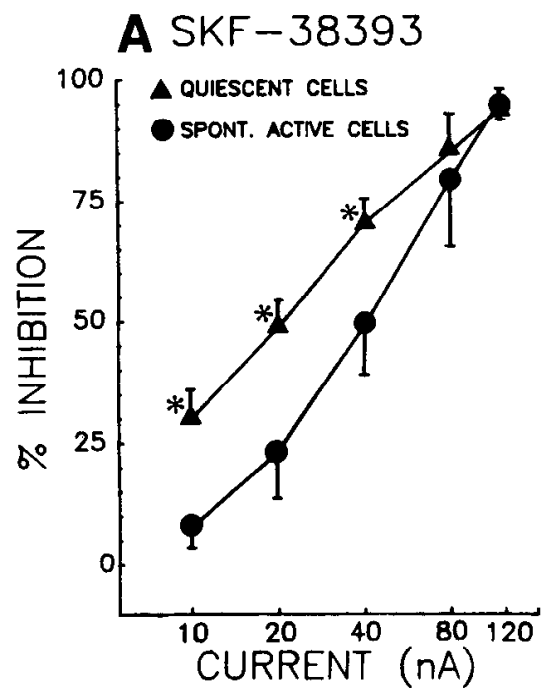

synaptic junctions with dendrites and the necks of dendritic spines (Pickel et al., 1981; Freund et al., 1984, 1985).

Compared with spontaneously active cells in the $\mathrm{CPu}$, quiescent cells activated by GLU were significantly more sensitive to $(+)$ SKF-38393; no such disparity was observed following administration of quinpirole. These results suggest that, under the normal condition, the activity of many CPu cells is inhibited tonically; the basal spontaneous release of DA in the CPu might bc sufficient to suppress the firing activity of a large number of $\mathrm{CPu}$ cells, and this action of DA is primarily mediated by the D-1 DA receptor subtype. Thus, these results again suggest that $\mathrm{D}-1$ receptors in the $\mathrm{CPu}$ have a critical role in mediating the effects produced by DA and DA agonists.

Unlike the effect of iontophoretically applied (+)SKF-38393, i.v. (+)SKF-38393 did not consistently depress the firing activ- ity of $\mathrm{CPu}$ cells. However, when $(+) \mathrm{SKF}-38393$ was injected immediately after quinpirole, the inhibitory action of $(+)$ SKF38393 was markedly enhanced. These results suggest that D-1 and D-2 receptor subtypes may interact in a synergistic fashion to affect the $\mathrm{CPu}$ neuronal activity, reminiscent of the finding of synergistic actions between $(+)$ SKF-38393 and quinpirole on cells in the substantia nigra pars reticulata (Carlson et al., 1987), globus pallidus (Walters et al., 1987), and NAc (White, 1987). Contrasting with the observation from the NAc (White, 1987) in which D-1 receptor stimulation facilitates or enables the inhibition induced by D-2 agonist, the present results suggest that in the $\mathrm{CPu}$ the selective $\mathrm{D}-2$ agonist potentiates the depressant action produced by D-1 agonist, although further studies are needed to elucidate the mode of interactions between D-1 and D-2 receptor agonists. Corresponding to our results was the
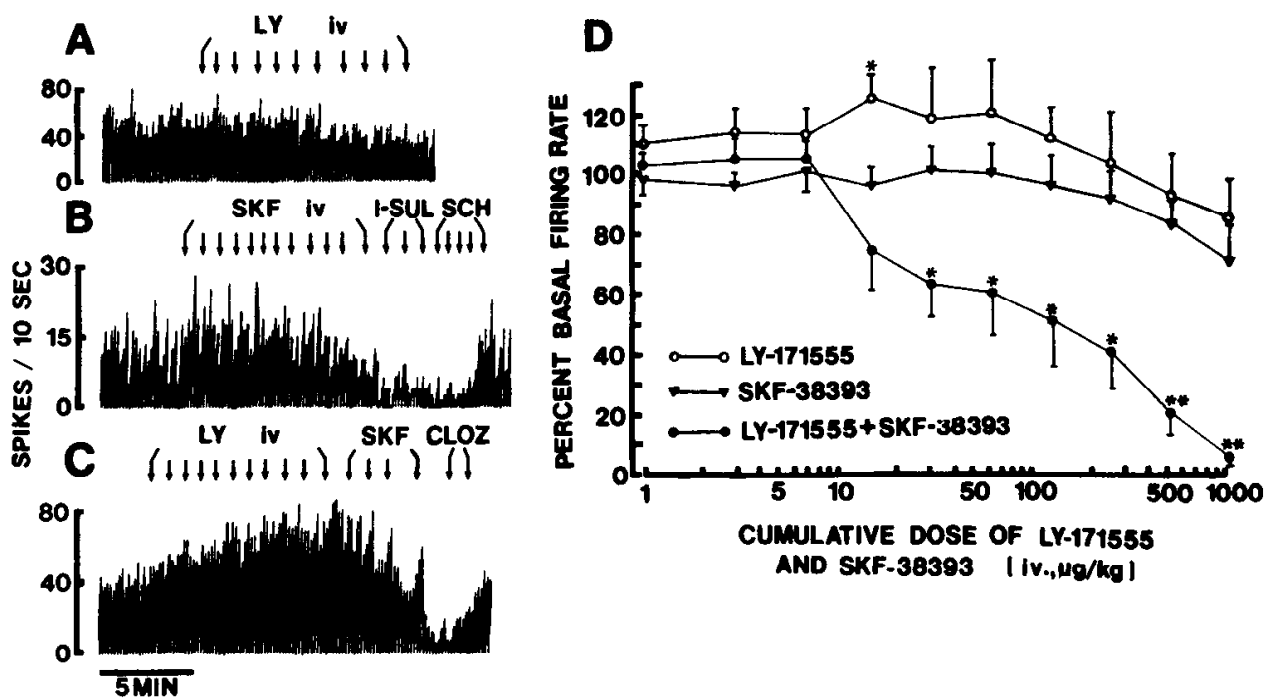

Figure 8 . Synergistic actions produced by i.v. administrations of D-1 and D-2 receptor agonists on CPu neurons. $A r r o w s$ in $A-C$ indicate i.v. injections of exponentially increasing doses of drugs starting at $0.001 \mathrm{mg} / \mathrm{kg}$. Quinpirole (LY-171555) was relatively ineffective in inhibiting the neuronal activity $(A)$. (+)SKF-38393, at high doses (total, $4.095 \mathrm{mg} / \mathrm{kg}$ ), sometimes suppressed the firing activity of CPu neurons $(B)$. When $(+)$ SKF-38393 (total, $0.015 \mathrm{mg} / \mathrm{kg}$ ) was administered immediately after the injection of quinpirole (total, $1.023 \mathrm{mg} / \mathrm{kg}$ ), the ability of $(+)$ SKF. 38393 to suppress the firing activity was markedly enhanced (cf. $B$ and $C$ ). On this neuron $(C)$, the effect produced by the combination of $(+)$ SKF38393 and quinpirole was reversed by the DA antagonist clozapine (CLOZ). Also note that low doses of quinpirole caused an initial increase in the firing activity. In $D$, the data points represent the means \pm SEM. Asterisks represent points that significantly differ from the corresponding points of $(+)$ SKF-38393 alone $\left({ }^{*} p<0.05,{ }^{* *} p<0.01\right.$, ANOVA with post hoc Newman-Keuls tests). 
clinical study showing that, when SKF-38393 was administered alone, it failed to improve symptoms of Parkinson's disease (Braun et al., 1987). The results from the present study suggest that combinations of both D-1 and D-2 agonists would be much more effective than either D-1 or D-2 agonists in treating parkinsonism.

Interestingly, concurrent iontophoresis of $(+)$ SKF-38393 and quinpirole primarily produced an additive effect with little synergistic action shown in the $\mathrm{CPu}$, similar to the result reported in the substantia nigra pars reticulata (Weick and Walters, 1987a). The reasons for these discrepant results obtained from the i.v. and iontophoretic administration are unclear. However, it is possible that the synergistic effect seen on $\mathrm{CPu}$ cells after intravenous administrations of D-2 and D-1 receptor agonists is mediated by receptors located in different DA target loci. It should be pointed out that the failing to show synergistic actions between $D-1$ and $D-2$ receptor agonists might be related to the fact that the DA transmission was not disrupted in our study. For unknown reasons, it has been reported that manipulations such as lesions of DA fibers or depletion of DA in the terminals, which block or interrupt DA transmission, facilitate the synergistic actions between D-1 and D-2 receptor agonists in some brain regions (Gershanik et al., 1983; Braun et al., 1986; Morelli et al., 1987; Starr et al., 1987; Weick and Walters, 1987b; White, 1987).

In summary, the results of the present study show that (1) both D-1 and D-2 DA receptor subtypes exist in the CPu of the rats; (2) in the $\mathrm{CPu}, \mathrm{D}-1$ receptors may play a major role in mediating both the "neuromodulatory" and "inhibitory" action of DA; and (3) although the precise loci for the interactions between $D-1$ and $D-2$ receptors are unclear at the present time, i.v. administration of quinpirole and $(+)$ SKF-38393 exhibit a marked syncrgistic action on $\mathrm{CPu}$ neurons. Whereas $\mathrm{CPu}$ cells are significantly more sensitive to $D-1$ than $D-2$ receptor agonist, the reverse is true for NAc cells. These results underscore the necessity for regional studies of neurotransmitters and drug action.

\section{References}

Akaike, A., Y. Ohno, M. Sasa, and S. Takaori (1987) Excitatory and inhibitory effects of dopamine on neuronal activity of the caudate nucleus in vitro. Brain Res. 418: 262-272.

Bernardi, G., M. G. Marciani, C. Morocutti, F. Pavone, and P. Stanzione (1978) The action of dopamine on rat caudate neurons intracellularly recorded. Neurosci. Lett. 8: 235-240.

Braun, A. R., and T. N. Chase (1986) Obligatory D1-D2 receptor coactivation and the generation of dopamine agonist related behaviors. Eur. J. Pharmacol. 131: 301-306.

Braun, A., G. Fabbrini, M. M. Mouradian, C. Serrati, P. Barone, and T. N. Chase (1987) Selective D-1 dopamine receptor agonist treatment of Parkinson's disease. J. Neural Transm. 68: 41-50.

Bunney, B. C., and A. A. Grace (1978) Acute and chronic haloperidol treatment: Comparison of effects on nigral dopaminergical cell activity. Life Sci. 23: 1715-1728.

Calabresi, P., N. Mercuri, P. Stanzione, A. Stefani, and G. Bernardi (1987) Intracellular studies on the dopamine-induced firing ihibition of neostriatal neurons in vitro: Evidence for D1 receptor involvement. Neuroscience 20: 757-771.

Carlson, J. H., D. A. Bergstrom, and J. R. Walters (1987) Stimulation of both D-1 and D-2 dopamine receptors appears necessary for full expression of postsynaptic effects of dopamine agonist: A neurophysiological study. Brain Res. 400: 205-218.

Chang, H. T., C. J. Wilson, and S. T. Kitai (1982) A golgi study of rat neostriatal neurons: Light microscope analysis. J. Comp. Neurol. 208: $107-126$.
Chiodo, L. A., and T. W. Bcrger (1986) Interactions between dopamine and amino acid-induced excitation and inhibition in the striatum. Brain Res. 375: 198-203.

Chiodo, L. A., and B. S. Bunney (1983) Proglumide: Selective antagonism of excitatory effects of cholecystokinin in central nervous system. Science 219: 1449-1451.

Creese, I., D. R. Sibley, M. W. Hamblin, and S. E. Leff (1983) The classification of dopamine receptors: Relationship to radioligand binding. Annu. Rev. Neurosci. 6: 43-71.

Freund, T. F., J. F. Powell, and A. D. Smith (1984) Tyrosine hydroxylase-immunoreactive boutons in synaptic contact with identified striatonigral neurons, with particular reference to dendritic spines. Neuroscience 13: 1189-1215.

Freund, T. F., J. P. Bolam, A. Bjorklund, U. Stenevi, S. B. Dunnett, J. F. Powell, and A. D. Smith (1985) Efferent synaptic connections of grafted dopaminergic neurons reinnervating the host neostriatum: A tyrosine hydroxylase immunocytochemical study. J. Neurosci. 5: 603616.

Fuller, R. Y., and S. K. Hemrick-Luecke (1985) Decrease in hypothalamic epinephrine concentration and other neurochemical changes produced by quinpirole, a dopamine agonist, in rats. J. Neural Transm. 61: 161-173.

George, S. R., M. Watanabe, T. Di Paolo, P. Falardeau, F. Labrie, and P. Seeman (1985) The functional state of the dopamine receptor in the anterior pituitary is the high-affinity form. Endocrinology 117 : 690-697.

Gershanik, O., R. E. Heikkila, and R. C. Duvoisin (1983) Behavioral correlates of dopamine receptor activation. Neurology 33: 1489-1492.

Grigoriadis, D., and P. Sccman (1985) Complete conversion of brain D-2 dopamine receptors from the high- to the low-affinity state for dopamine agonists, using sodium ions and guanine nucleotide. J. Neurochem. 44: 1925-1935.

Hahn, R. A., B. R. MacDonald, and M. A. Martin (1983) Antihypertensive activity of LY-141865, a selective presynaptic dopamine receptor agonist. J. Pharmacol. Exp. Ther. 224: 206-214.

Hand, T. H., X.-T. Hu, and R. Y. Wang (1987) Differential effects of typical and atypical antipsychotic drugs on the activity of dopamine neurons and their postsynaptic target cells. In Neurophysiology of Dopaminergic Systems-Current Status and Clinical Perspectives, $\mathbf{L}$. A. Chiodo and A. S. Freeman, eds., pp. 141-164, Lakeshore Publishing, Michigan.

Herrling, P. L., and C. D. Hull (1980) Iontophoretically applied dopaminc depolarizes and hyperpolarizes the membrane of cat caudate neurons. Brain Res. 192: 441-462.

Hu, X.-T., and R. Y. Wang (1986) Differential effects of haloperidol and clozapine in the rat neostriatum and nucleus accumbens: Microiontophoretic studies. Soc. Neurosci. Abstr. 12: 1389.

Hu, X.-T., and R. Y. Wang (1988) Disinhibitation of nucleus accumbens neurons by the dopamine D2 receptor agonist LY-141865: Prevented by 6-OHDA pretreatment. Brain Res. 444: 389-393.

Johnson, S. W., M. R. Palmer, and R. Freedman (1983) Effects of dopamine on spontaneous and evoked activity of caudate neurons. Neuropharmacology 22: 843-851.

Kebabian, J. W., and D. B. Calne (1979) Multiple receptors for dopamine. Nature 277: 93-96.

Knapp, A. G., and J. E. Dowling (1987) Dopamine enhances excitatory amino acid-gated conductances in cultured retinal horizontal cells. Nature 325: 437-439.

Lacey, M. G., N. B. Mercuri, and R. A. North (1987) Dopamine acts on D2 receptors to increase potassium conductance in neurons of the rat substantia nigra zona compacta. J. Physiol. (Lond.) 392: 397-416.

Martin, J. R., M. C. Beinfeld, and R. Y. Wang (1986) Modulation of cholecystokinin release from posterior nucleus accumbens by D-2 dopamine receptor. Brain Res. 397: 253-258.

Meunier, H., and F. Labrie (1982) The dopamine receptor in the intermediate lobe of the rat pituitary gland is negatively coupled to adenylate cyclase. Life Sci. 30: 963-968.

Minneman, K. P., L. R. Hegstrand, and P. B. Moniloff (1979) The pharmacological sensitivity of beta-1 and beta- 2 adrenergic receptors in rat heart and lung in vitro. Molec. Pharmacol. 16: 21-33.

Morelli, M., S. Fenu, and G. Di Chiara (1986) Behavioural expression of D-1 receptor supersensitivity depends on previous stimulation of D-2 receptors. Life Sci. 40: 245-251.

Ohno, Y., M. Sasa, and S. Takaori (1986) Excitation by dopamine D-2 receptor agonists, bromocriptine and Ly-171555, in caudate nu- 
cleus neurons activated by nigral stimulation. Life Sci. 38: 18671873.

Onali, P., J. P. Schwartz, and E. Costa (1981) Dopaminergic modulation of adenylate cyclase stimulation by vasoactive intestinal peptide (VIP) in anterior pituitary. Proc. Natl. Acad. Sci. USA 78: 6531 6534.

Paxinos, G., and C. Watson (1982) The Rat Brain in Stereotaxic Coordinates, Academic, New York.

Pickel, V. M., S. C. Beckley, T. H. Joh, and D. J. Reis (1981) Ultrastructural immunocytochemical localization of tyrosine hydroxylase in the neostriatum. Brain Res. 225: 373-385.

Pinnock, R. D. (1984) The actions of antipsychotic drugs on dopamine receptors in the rat substantia nigra. Br. J. Pharmacol. 81: 631-635.

Seeman, P. (1987) Dopamine receptors and the dopamine hypothesis of schizophrenia. Synapse 1: 133-152.

Seeman, P., D. E. Grigoriadis, and H. B. Niznik (1986) Selectivity of agonists and antagonists at D-2 dopamine receptors compared to D-1 and S-2 receptors. Drug Dev. Res. 9: 63-69.

Setler, P. E., H. M. Seran, C. L. Zirkle, and H. L. Saunders (1978) The central effects of a novel dopamine agonist. Eur. J. Pharmacol. 50: $419-430$

Sibly, D. R., A. De Lean, and I. Creese (1982) Anterior pituitary dopamine receptors: Demonstration of interconvertible high and low affinity states of D-2 dopamine receptor. J. Biol. Chem. 257: 63516361.

Siggins, G. R. (1978) Electrophysiological role of dopamine in striatum: Excitatory or inhibitory? In Psychopharmacology. A Generation of Progress, M. A. Lipton, A. Di Mascio, and K. F. Killiam, eds., pp. 143-157, Raven, New York.

Siggins, G. R., B. H. Hoffer, and U. Ungerstedt (1974) Electrophysiological evidence for involvement of cyclic adenosine monophosphate in dopamine response of caudate neurons. Life Sci. 15:779792.

Silva, N. L., and B. S. Bunney (1986) Electrophysiological properties of dopamine-sensitive neurons in substantia nigra tissue slices. Soc. Neurosci. Abstr. 12: 1517.

Skirboll, L. R., and B. S. Bunney (1979) The effects of acute and chronic haloperidol treatment on spontaneously firing neurons in the caudate nucleus of the rat. Life Sci. 25: 1419-1434.

Starr, B. S., M. S. Starr, and I. C. Kilpatrick (1987) Behavioral role of dopaminc D-1 receptors in the reserpine-treated mouse. Neuroscience 22: 179-188.

Stoof, J. C., and J. W. Kebabian (1981) Opposing roles for D-1 and
D-2 dopamine receptors in efflux of cyclic AMP from rat neostriatum. Nature 294: 366-368.

Tamminga, C. A., and J. Gerlach (1987) New neuroleptics and experimental antipsychotics in schizophrenia. In Psychopharmacology The Third Generation of Progress, H. Y. Meltzer, ed., pp. 1129-1140, Raven, New York.

Titeler, M., R. A. Lyon, K. H. Davis, and R. A. Glennon (1987) Selectivity of serotonergic drugs for multiple brain serotonin receptors. Biochem. Pharmacol. 36: 3265-3271.

Walters, J. R., D. A. Bergstrom, J. H. Carlson, T. H. Chase, and A. R. Braun (1987) D-1 dopamine receptor activation required for postsynaptic expression of D-2 agonist effects. Science 236: 719-722.

Wang, R. Y. (1981) Dopaminergic neurons in the rat ventral tegmental area. I. Identification and characterization. Brain Res. 3: 123-140.

Wang, R. Y., C. Demontigny, B. I. Gold, R. Y. Roth, and G. K. Aghajanian (1979) Denervation supersensitivity to serotonin in rat forebrain: Single cell studies. Brain Res. 178: 479-497.

Wang, R. Y., F. J. White, G. Mereu, and X.-T. Hu (1987) Electrophysiological analysis of dopamine receptor subtypes. In Dopamine Receptors, I. Creese and C. M. Fraser, eds., pp. 153-173, Liss, New York.

Waszczak, B. L., and J. R. Walters (1982) Dopamine modulation of the effects of gamma-aminobutyric acid on substantia nigra pars reticulata neurons. Science 220: 218-221.

Weick, B. G., and J. R. Walters (1987a) Do D-1/D-2 receptor interactions occur directly in the substantia nigra pars reticulata? Soc. Ncurosci. Abstr. 13: 489.

Weick, B. G., and J. R. Walters (1987b) Effects of D-1 and D-2 dopamine receptor stimulation on the activity of substantia nigra pars reticulata neurons in 6-hydroxydopamine lesioned rats: D-1/D-2 coactivation induces potentiated responses. Brain Res. 405: 234-246.

White, F. J. (1987) D-1 dopamine receptor stimulation enables the inhibition of nucleus accumbens by a D-2 receptor agonist. Eur. J. Pharmacol. 135: 101-105.

White, F. J., and R. Y. Wang (1983) Comparison of the effect of chronic haloperidol treatment on $\mathrm{A} 9$ and $\mathrm{A} 10$ dopamine neurons in the rat. Life Sci. 32: 983-993.

White, F. J., and R. Y. Wang (1986) Electrophysiological evidence for the existence of D-1 and D-2 dopamine receptors in the rat nucleus accumbens. J. Neurosci. 6: 274-280.

York, D. H. (1979) The neurophysiology of dopamine receptors. In The Neurobiology of Dopamine, A. S. Horn, J. Korf, and B. H. C. Westerink, eds., pp. 395-415, Academic, New York. 